\title{
Mengangankan HAM Indonesia Berwawasan Islam
}

\author{
EmefZenrif
}

\section{Problematika Konsep Ham}

Umat Islam Indonesia apabila diháapkan pada permasalahan-permasalahan sosial, terutama yang berkaitan dengan hukum dan peradilan, selalu melibatkan dualisme pemikiran, keislaman dan kindonesiaan. Ketika permasalahan Hak Asasi Manusia (HAM) muncul, unat Islam Indonesia berusaha mencarikan justifikasi permasalahan tersebut ke dalam syari'atmya. Hal ini wajar-wajar saja, sebab Islam cliyakini tidák sekedar mngatur spiritualitas umatnya, tetapi juga menyangkut aturan-aturan sosial. Sebab ini pula, dalam sejarah panjang cendekiawan muslim Indonesia selalu mempunyai dua tampakan, mereka yang berusaha menjadikan syari'at. Islam sebagai aturan hidup bernegara secara formal (formalistik), dan mereka yang berusaha memasukkan nilai-nilai dan esensi syari'at sebagai ruh dalam kebijakan-kebijakan formalitas (substansialistik).

Permasalahan HAM, bila dilihat dalam perspektif kemanusiaannya, agak sulit dicarikan rujukan yang

valid. Sebab, kesadaran akan eksistensi kemanusiaan muncul bersamaan dengan wujud dirinya. Artinya, sejak awal manusia ada di muka bumi, ia telah menyadari eksistensi dan nilai-nilaị kemanusiaannyà, sekalipun ticlak menggunakan term yang demikian. Permasalahan ini baru akan ditemukan sebagai sebuah kesepakatan bersama dalam perspektif sejarah politik (polilical bistory) negara-bangsa.

Dalam sejarah politik negara-bangsa term HAM dapat ditemukan dalam ketetapan Perserikatan BangsaBangsa (PBB) tentang Universal Declaration of Human Rigbt pada tanggal 10 Desember $1948^{!}$. Dalam deklarasi HAM internasional tersebut, HAM dipandang sebagai upaya definitif dari pengakuan hak dan nilai kemanusiaan oleh manusia lainnya. Dengan kata lain, HAM universal merupakan frame of reference negaranegara untuk memberikan batasan-batasan yang dicerminkan dalam ketetapan dan aturan internasional tentang kebijaḳan dan pembatasan tindakan manusia atas manusia lainnya. Oleh sebab itu, setiap bangsa pasti mempunyai sumber filosofi kenuanusiaan yang berbedabeda. Hal ini, berkonsekuensi logis pada perbedaan ketetapan HAM internasional dan nasional.

Pada sisi lain, konsep Universal of Human Rights
Pada sisi lain, konsep Universal of Human Rights tersebut secara konstitusional mengacu pada dan ditegakkan melalui institusi internasional yang dicetuskan oleh PBB. Akan tetapi, Piagam tersebut tidak dapat menfasilitasi term-term definitif dari masing-masing negara yang mempunyai perbedaan trame of relerence? tersebut secara konstitusional mengacu pada dan ditegakkan melalui institusi internasional yang dicetuskan oleh PBB. Akan tetapi, Piagam tersebut tidak dapat menfasilitasi term-term clefinitif dari masing-masing negara yang mempunyai perbedaan frame of reference ${ }^{2}$. Hal ini menjadikan ketegangan penegakan HAM universal, antara kepentingan internasional dan nasional. Pada tataran ini, PBB sering berupaya melakukan intervensi terhadap negera-negara lain dengan alasan HAM. Posisi PBB yang demikian, tentu, tidak menguntungkan pada penegakan HAM di masingmasing negara. Disinilah kesulitan khusus operasionalisasi HAM.

Kesulitan di atas masih ditambah lagi dengan kesulitan internal masing-masing negara. Kesulitan internal itu banyak disebabkan permasalah political will cari pmerintah masing-masing. Indonesia, misalnya, sebagai negara yang baru bangun dari pelanggaran HAM yang tak terkendalikan, mempunyai kesulitan dari kedua sisi, konseptual dan operasional. Secara konseptual kesulitan itu kian diperburuk disebabkan negara ini 
selama 53 tahun tidak menyediakan file-file yang bisa dijadikan rujukan terbentuknya konsep HAM nasional yang memadai, kecuali sebagian kecil ketentuan dasar yang tertuang dalam UUD 1945. Sekalipun KUHP dan KUHAP bisa dijadikan rujukan awal terbentuknya hukum dan peradilan HAM, akan tetapi keterpurukan peradilan dan perundang-undangan dalam "catatan hitam" sejurah bangsa ini tidak dapat menggambarkan bahwa KUHP dan KUHAP merupakan nilai-nilai kemanusiaan yang diangkat melalui dasar-dasar filosofis bangsa yang humanis ini.

Pada tataran operasional, pemerintah rupanya mendapatkan kendala yang cukup serius sebab ketergantungannya pada eksistensi peradilan yang baru akan diterbitkan perundangundangannya. Belum lagi beberapa permasalahan HAM di masa lalu, turut mempersulit terbentuknya supremasi HAM nasional, tanpa interensi dari pihak luar. Hal ini disebabkan hukum nasional tidak berlaku surut. Lalu, apa yang bisa diperbuat umat Islam sebagai mayoritas masyarakat negerinya tercinta dalam menghadapi permasalahan tersebut? Bisakah
Pada tataran operasional, pemerintah rupanya mendapatkan kendala yang cukup serius sebab ketergantungannya pada eksistensi peradilan yang baru akan diterbitkan perundangundangannya. Belum lagi beberapa permasalahan HAM di masa lalu, turut mempersulit terbentuknya supremasi HAM nasional melindungi HAM. Prinsip-prinsip tersebut mencakup bebagai hal yang sangat luas, meliputi hak mendapatkan keamanan jiwa, hak kemerdekaan dalam menentukan sikap, ideologi, keyakinan dan agama, hak keadilan dan persamaan di depan hukum tanpa diskriminasi sosial, rasial dan agama, hak memperoleh pengayoman dan pendidikan, hak kebebasan berusaha dan kepemilikan personal, hak keamanan dari penganiayaan dan ancaman, hak pembelaan clalam tuduhan, an masih banyak lagi hak-hak yang diberikan Islam dan tak mungkin dituangkan keseluruhannya dalan keterbatasan ruang ini. Kali ini, kita hanya akan membahas tiga hak yang disbutkan pertama.

\section{Hak Keamanan Jiwa}

Masalah jiwa manusia adalah masalah yang paling esensi dalam eksistensi manusia, sebab pengakuan terhadap kemanusiaan sesungguhnya merupakan pengakuan terhadap eksistensi jiwanya. Untuk itu, Islam memberikan perhatian serius terhadap masalah ini dengan melalui tiga tahap. Pertama, Islam menerapkan teori penyadaran akan nilai kemanusiaan. Dalam hal ini alQur'an menggambarkan bahwa umat Islam berpacu menegakkan hukum untuk kepentingan internal Islam dan nasional? Aclakah Islam menyediakan hukum HAM untuk bangsa ini ? Jawabaln dari permasalahan inilah yang akan diusahakan jawabannya dalam tulisan sederhana ini.

\section{Prinsip-Prinsip HAM dalam Islam}

Apologis atau tidak, sebagian orang menganggap bahwa syari'at Islam mengatur masalah HAM. Apabila yang dimaksudkannya adalah hukum syara' secara keseluruhan, ternasuk yang tercerap dalam fiqh sosial dan siyasah, maka Islam memang mengatur masalah ini. Sebab, pada dasarnya setiap substansi dan nilai syari'at Islam bisa dikategorikan dalam hukum yang dapat eksistensi personal adalah representasi dari eksistensi universal (QS. Al-Ma'idah (5) : 32). Pembunuhan terhadap personal sama dengan pembunuhan terhadap eksistnsi kemanusiaan universal. Sebaliknya, menghidupi personal merupakan kebajikan terhadap upaya kemanusiaan universal. Suatu kebajikan yang tiada taranya!

Kedha, melalui pmberian motivasi psikologis untuk tidak membunuh manusia dengan secara tidak sah dan zalim (QS. al-An'am(6) : 151). Bahkan, Islam melarang membunuh diri sendiri (QS. Al-Nisa'(4) : 29). Prinsip yang disebutkan terakhir ini membuktikan bahwa Islam tidak hanya memberikan pengertian terhadap pentingnya pemahaman terhaclap eksistensi orang lain, akan tetapi 
lebih daripada itu eksistensi dirinya sendiri adalah representasi dari kosmik yang lebih luas. suatu konsep penyadaran tentang eksistensi manusia yang tidak ditemukan dalam konsep HAM modern.

Ketiga, melalui pemberian sangsi yang berat terhadap orang lain yang melanggar hak ini. Apabila pembunuhan terhadap jiwa personal dilakukan dengan sengaja, maka hukuman yang terberat, sekali lagi terberat, adalah dihukum mati (qisbab)(QS. Al-Bäqarah (2) : 178). Akan tetapi, apabila pelanggaran itu dilakukan dengan tidak sengaja, ia diharuskan membebaskan sifat pebudakan orang lain dengan jalan membebaskan perbudakan (QS. al-Nisa' (4) : 92), sebuah sangsi yang berorientasi pada penegakan dan peningkatan nilai-nilai humanis.

Untuk itu, prinsip ini tidak bisa dihadapkan clengan konsep jibad fi sabilillab dalam Islam. Sebab, di samping konsep tersebut masih-sangat interpretable, ia masih merupakan konsep konsep yang hanya bisa dioperasionalisasikan dalam kondisi mimbela diri (QS: al-Baqarah (2) : 190-191) atau secara politis mengadakan penyerangan balik (recounter) atas serangan lawan (QS. Al-Taubah (9)：56), apalagi, dalam sejarah-sejarah - pejuangan Rasulullah Muhammad, kondisi objektifnya menunjukkan terhadap penegakan nilaí-nilai kemanusiaan dengan melarang pembunuhan terhadap lawan yang menyerahkan diri, orang tua, anak, dan orang-orang Imah dan tak berdosa.

\section{Hak Kebebasan Memilih Keyakinan dan Agama}

Di samping jiwa, hak yang paling asasi dalam diri manusia adalah penentuan terhadap sikap dan keyakinannya. Sebab, keyakinan itu dapat berpengaruh terhadap perilaku dan produktifitas manusia ${ }^{4}$ Untuk itu, prinsip kebebasan menentukan keyakinan dan agama adalah prinsip yang paling asasi. Islam memberikan perhatian terhadap term ini dengan penegasanpenegasan. Pertama, sslam menegaskan bahwa agama adalalı hal yang sangat personal, sehingga tidak ada yang dapat memaksakan oang lain melakukan konversi agama atau konvergnsi spiritualitas keagamaan (QS. al-Kafirun (109) : 6).

Kedua, Islam menegaskan garis dan konsep-konsep kebaikan dan membedakannya dari kebatilan (QS. alBaqarah (2) : 256), dan tetap niembiarkan manusia memilih kebaikan dan kebatilan dengan berdasarkan pada keyakinannya (QS. al-Kahf (18) : 29), tentu dengan konsekuensi masing-niasing sebagai pertanggung jawaban dari pilihannya.

Prinsip ini memberikan penegasan atas dua hal; (a) keyakinan manusia hanya dapat ditegakkan di atas keyakinan, kesaclaran dan ketundukan sendiri, yang hal ini hanya bisa dicapai apabila keyakinan itu bukan atas beban pemaksaan orang lain. ${ }^{5}$ dan (b) menunjukkan penegasan pada kesadaran Islam akan tegaknya pluralisme keagamaan umat manusia:

\section{Hak Kesamaan dan Keadilan di Depan Hukum}

Sudah ketentuan yang taken for granted rasanya, bahwa manusia memipunyai kecenderungan diskriminatif berdasarkan standarnya sendiri. Kecenderungan ini mengakibatkan terpuruknya supremasi hukum. Tak jarang kita melihat suatu kebijakan yang cenderung menguntungkan suatu pihak dan merugikan pihak lain. Prinsip Islam menegaskan hal ini dengan meletakkan clasar-dasar kesamaan dan keadilan di depan hukum (syari'at).

Islam menjelaskan bahwa manusia berasal dari struktur biologis yang sama (QS. al-Nisa' (4) : 1) yang darinya dikembangkan bangsa-bangsa yang mempunyai perbedaan kultur dan kondisi sosial (QS. Al-hujurat (49:13). Berdasarkan hal itu, maka standarisasi stratifikasi sosial hanya berdasarkan terhadap kemampuan spiritualitasnya, seperti yang disebutkan diakhir ayat 13 surat al-Hujurat (49).

Kesadaran akan kesamaan ini, memberikan clorongan agar manusia dapat melakukan perlakuan adil dalam menentukan hukum (QS. Al-Nisa' (4):57), tanpa membedakan keturunan (QS. al-Maiclah (5):8, al-An'am (6):152) atau agama (QS. Al-Ma'idah (5) : 42). Prinsip ini menjadi landasan ideal atas terbentuknya suatu masyarakat yang addil, makmur dan sejahtera.

\section{Strategi Implementasi Prinsip HAM Islam}

Prinsip HAM yang dijelaskan pada bagian sebelum - ini clan yang sebagiannya ticlak terbahas, setidaknya, dapat cijacdikan sebagai bahan renungan terbentuknya seluruh konsep HAM Islam. Upaya penegakan HAM di Indonesia sangat memungkinkan umat Islam mencari pintu gerbang untuk memasukkan nilai-nilai humanisme Islam chapat tercerap, secara eksplisit atau implisit, dalam 
HAM nasional. agar konsep itu dapat dioperasionalisasikan, kita perlu memperhatikan tiga hal utama yang terkandung dalam hukum Islam secara umum. Pertama, bahwa hukum Islam bersifat universal (tidak trbatas ruang dan waktu) ${ }^{6}$. Sifat universalisme hukum İslam tidak dapat diketahui dengan jalan "melucuti" hukum Islam secara tekstual, sebab mayoritas hukum Islam yang universal adalah yang substansial, dan untuk memahaminya hanya bisa jika melalui pendekatan kontekstual. Untuk itu, pemahaman terhaclap cerapan sejaral, kultur dan lingkungan masyarakat dimana hukum itu "diterbitkan", harus menjadi fokus utana agar dapat memahami substansi dan esensi syari'at (magasbid al-syari'ab).

Kedua, bahwa hukum Islam tidak pernah berlaku surut. Ia hanya dapat berlaku setelah "penerbitannya" dan memberikan pengampunan atas pelanggaran hukuni yang dikerjakan sebelunnya. Sebut saja misalnya masalah hukum haram dalam praktik ribawi. Keharaman riba "diterbitkan" pada akhir tahun VIIl atau awal tahun IX $\mathrm{H}^{7}$ dengan berdasarkan terhadap turunnya QS AlBaqarah (2) : 275 . Dalam ayat tersebut dijelaskan bahwa praktik ribawi yang dikerjakan sebelum ayat ini diturunkan dimaafkan, bukan dibenarkan. ${ }^{*}$

Pandangan ini tentu tidak bermaksud memberikan maaf tanpa proses hukum terhadap mereka yang melanggar HAM di Indonesia. Sebab, sekalipun Indonesia masih belum mempunyai ketetapan hukum dan peradilan HAM, akan tetapi secara kolektif seluruh kesalahan dan pelanggaran HAM di Indonesia dapat dimasukkan dalam pelanggaran HAM universal yang secara institusional hanya bisa dilakukan oleh pengadilan yang ditetapkan PBB, sebagai "polisi" dunia.

Ketiga, bahwa hukum Islam tidak memberikan beban kecuali pada pelakunya. Banyak ayat yang dapat menjelaskan hal ini, misalnya QS. al-An'am (6) : 164 dan QS. al-Isra' (17) : 15 yang menjelaskan bahwa pembebanan hukum hanya berlaku bagi mereka yang melakukan, dan tidak ada pemberian beban bagi orang lain, kecuali ia adalah orang bertanggung jawab atas pelanggaran itu baik disebabkan ia adalah pemimpin yang melalaikan amanah yang dibebankan padanya (QS. Al-Nisa' (4) : 57, atau karena ikut andil dalam praktik pelanggaran, baik secara langsung maupun tidak langsung (QS. Al-Nahl (16) : 25).

Berpijak pada pandangan terakhir ini, kita memahami bahwa pemerintah, dengan tetap mempertahankan model dan struktur pemerintahan seperti sekarang ini, ticlak begitu saja dapat divonis sebagai penanggung jawab atas seluruh pelanggaran HAM atau kerusuhan yang terjadi belakangan ini. Sebab, ketetapan amanah tidak ditentukan berdasarkan kepentingan temporal dan regional. Ia lebih merupakan sebuah beban dan tanggung jawab dalam permasalahanpermasalahan dalam skala nasional, sedangkan penanggung jawab kondisi regional, sepenuhnya berada dalam amanah pemerintah daerah. Wallabu A'lam.

${ }^{1}$ Mengenai sejarah HAM baca misalnya Anwar Hardjono, Indonesia Kila:Bervawasan Iman-Islam. (Cet.I; Jakarta : Gema Insani Press, 1995),h. 112 dst.

${ }^{2}$ Mengenai permasalahan konseptual HAM universal lihat dalam Abdullah Ahmed An-Na'im, "Torvards an Islamic Reformation: Civil Liberties, human Rights and International Law", diterjemahkan oleh Ahmad Soaedy dan Amiruddin Arrani, Dekonsiruksi Syari'ab (Cet. I; Yogyakarta: LkiS, 1994), h. 308 dst.

${ }^{3}$ Lihat logika ini dalam Nurcholish Madjid, Masyarakat Religius (Cet. I; Jakarta Paramaina, 1997), h. 68 .

${ }^{4}$ Mengenai hal ini baca M. Dawam Rahardjo, Intelektual Inteligensia dan Perilaku Politik Bangsa; Risalab Cendekiawan Muslim (Cet. I; Bandung : Mizan, 1993), h. 386 dst.

'Lihat penafsiran ini alam Ahmad Mushtofa alMaraghi, Tafsiral-Maraghi, jilid III (tt. Dar al-Fikr, 1974), h. 16-17.

"Mengenai universalisme dan partikularisme Islam bacal M. Quraish Shihab, "Membumikan" Al-Qur'an (Cet. XIV; Bandung, Mizan, 1997), h. 213 dist.

${ }^{7}$ Abdul Aziz Dahlan et. al. (eds.), Ensiklopedi Hukum Islam. (Cet. I; Jakarta; P'T: Ichtiar Baru van Hoeve 1997), h. 1497.

${ }^{8}$ Contoh lain dari pemberian pengampunan dalam masalah yang berbeda adalah (QS. Al-Nisa' (4):22-23, dimana dijelaskan bahwa praktik pekawinan dengan ibu dan mengumpulan dua saudara dalam satu 